\title{
Çevirmen kuşdili mi konuşur?
}

\section{Osman COŞKUN'}

APA: Coşkun, O. (2020). Çevirmen kuşdili mi konuşur? RumeliDE Dil ve Edebiyat Araştırmaları Dergisi, (18), 673-687. DOI: 10.29000/rumelide.706471

\section{Öz}

Türetme dile yeni sözcükler kazandırmak için başvurulan yollardan biridir. Kavram üretimi ile türetme çeviribilimde karşılık bulan bir başlıktır. Çevirmeler, kaynak metininde karşılaştıkları yeni sözcük, terim ve kavramları erek dilde yeni bir sözcük, terim ve kavram ile karşılamak durumunda kalırlar. Sözcük türetmenin değişik yolları vardır. Çevirmen dile yeni kelimeler kazandırırken öneri(len) sözcügün bir yandan anlamı karşılama düzeyini, bir yandan erek dil yapısına uygunluğunu, bir yandan da toplum tarafından benimsenebilirliğini göz önünde bulundurur. Yazın geçmişinde çevirmenlerimiz öztürkçe kullanımı nedeniyle toplum tarafından benimsenebilirlik bağlamında eleştirilmiştir. 1940'larda kurulan Tercüme Kurulu çıkardığı Tercüme dergisiyle geniş kitlelere ulaşmıştır. 1967 üyelerinin istifasıyla kurul işlevsiz hale gelmiş, dergi yayınları durmuştur. Bu süreçte adına ister arı dil, ister öztürkçe süreci denilsin dilde özleşme yanlısı ve karşıtı akımlar oluşmuştur. Çevirmenler, kitaplar ve tercüme dergisi aracılığıla arı dil kullanarak, yeni kavramlar üreterek, türetilen sözcükleri çevirilerinde kullanarak Türk diline büyük katkı yapmışlardır. Öztürkçe karşıtları, tercüme dergisi ve diğer çevirilerinde ürettikleri kavramlar kullandıkları dil nedeniyle sık sık çevirmenleri kuşdili ve uydurma dil kullanmakla eleştirirler. Çevirmenler tarafından yapılan çevirilerinin toplum tarafından anlaşılmadığını savunurlar. Bu çalışmada 1967 yılında tercüme kurulu üyelerinin istifaları ertesinde, eleştirilere konu olan yeni sözcüklere, yapılan eleştirilere, değinilecektir. Çeviride kavram üretiminin önemine vurgu yapılıp, çeviribilim özelinde yeni sözcük türetmeye yollarına değinilecektir. Ayrıca yapılan kavram üretimine ve çeviriye yer verilecektir. Bu çalışmanın temel amacı çalışmaya konu olan dönemde çeviribilim bağlamında dilimize yeni giren sözcüklerle ilgili görüş ve değerlendirmelerin ortaya konulmasıdır. Diğer bir amacı bu sözcüklerin günümüzde kullanımı ve benimsenmesi konusunda saptamalar yapmaktır.

Anahtar kelimeler: Kavram üretimi, türetme, çeviri, eleştiri.

\section{Do translators speak bird language?}

\begin{abstract}
Derivation is one of the ways applied to bring new words to the language. Derivation and Neologism are the titles used in the context of translation studies. Translations have to supply the new words, terms and concepts they encounter in the source language with the new words, terms and concepts in the target language. There are different ways to derive words. As the translator brings new words to the language, he/she takes the level of supplying the meaning of recommended word, on one hand concordance of it to the structure of target language and on the other hand adoptability by the society into consideration. In our literary history, our translators were criticized in the context of adoptability by the society because of the use of pure Turkish. Translation Council, founded in 1940's, reached the
\end{abstract}

1 Dr. Öğr. Üyesi, Marmara Üniversitesi, Fen Edebiyat Fakültesi, Mütercim Tercümanlık Bölümü (İstanbul, Türkiye), osman.coskun@marmara.edu.tr, ORCID ID: oooo-0002-6803-3189 [Makale kayıt tarihi: 14.02.2020-kabul tarihi: 20.03.2020; DOI: 10.29000/rumelide.706471] 


\begin{abstract}
large audience with the translation journal it published. In 1967, with the resignation of its members, the council became dysfunctional and the publication of the journal stopped. In this process, whether it is called pure language or pure Turkish, pro and anti-purification of the language movements were formed. Translators made a great contribution to the Turkish by using pure language by means of books and translations journal, by neologism and by using derived words in other translations. Pure Turkish opponents often criticize the translators for using bird language or artificial language because of the concepts they derive in translation journal and in other translations and for the language they use. They argue that the translations made by the translators are not understood by the society. In this study, new words mentioned in criticism raised against to them, following the resignations of the members of the translation council in 1967 will be mentioned. The importance of neologism in translation will be emphasized, and the ways of deriving new words in translation studies will be mentioned. In addition, neologism and translation will be included. The main purpose of this study is to reveal the views and evaluations about the new words brought to our language in the context of translation studies in the period which is the subject of the study. Another aim is the determination of the usage of these words today.
\end{abstract}

Keywords: Neologism, derivation, translation, criticism.

\title{
Giriş
}

Sözcük sayısının çokluğu, her bir nesne ve kavramın ayrı bir sözcük ile karşılanabilirliği ve türetme olanağının bolluğu bir dilin zenginliğinin en önemli göstergelerindir. Kavram üretimi çeviribilim alanında incelenme alanı bulan bir başlıktır. Diller arası çeviri sürecinde bazen bir kopukluğa yol açabilir. Kavram üretimi ve çeviri bağlamında M. Deroy; "Bir dil bir kelimeye ihtiyaç duyduğunda, ya ona uyar ya da onu kendine uydurur.” Der (Akt. Darbelnet:). Bu çalışmada çeviribilim bağlamında kavram üretme, terim ve sözcük türetme konularına değinilecektir. 1967 yllında Tercüme Kurulu üyelerinin istifası sürecinde çevirmenlere yapılan eleştiriler kavram üretimi açısından yorumlanıp değerlendirilecektir.

Aksan (1982:153) kavramı şu şekilde açıklar:

1. Kavram, dünyadaki nesnelerin, olgu durum ve devinimlerinin dilde anlatım buluşudur. Bu anlatım, tuz, ip, su; yüreklilik, çöpçatan, açlık; hasıraltı, tepeden inme, açıkgöz gibi değişik ses ve biçimlerle, değişik yollardan gerçekleşir; somut ve soyut diye nitelediğimiz kavramları oluşturur.

2. Kavram, dünyadaki nesnelerin ortak niteliklerine dayanan, dile özgü bir genelleme, bir soyutlamadır: ağaç, bitki, hayvan, çiçek, memeli... gibi.

L. Weisgerber çevirmenin, dünyanın herhangi bir parçasını görüntüleyen bir fotoğrafın altına değişik bir altyazı koymakla yetinen kişi olmadığını, görevinin kaynak dildeortaya çıkan dilsel olguyu anlamak ve bunu anadilinin kendisine sunduğu olanaklar yardımıyla açıklamak olduğunu belirtir (akt. Dobossy: 166). Vardar (2001: 108), çeviri sorunlarını kaynak dil / erek dil bağlamında bildirinin çeşitli yönlerden anlam kaybına uğramasına bağlar. Bunun kökeninde kültürel ve toplumsal nedenlerin, deyişle bağlantılı sorunların ve dilsel nedenlerin olduğunu belirtir. Burada vurgulanmak istenen temel kayg çeviride kavram üretiminin yeterli görülmeyişidir. Atatürk "Ülkesini, yüksek istiklâlini korumasını bilen Türk milleti, dilini de yabancı diller boyunduruğundan kurtarmalıdır" (Arısoy, 1962: 3) diyerek yabancı dil karşısında ezilmeden, kırılmadan, bozulmadan dilde kavram üretimine dikkat çekmiştir. Yücel (2000:23); dil devriminin yerleşmesinde ve benimsenmesinde bilinçli çevirmenlerin işlevlerinin önemine dikkat çeker. Kimileri yapıtlarında yeni sözcükleri doğallaştııır, kimileri yeni sözcükler yaratır, 
kimileri de yöresel ağız zenginliklerini işler. Ahmet Mithat Efendi, Tercüman-ı Hakikat gazetesinde "Yazıklar olsun ki, biz şimdiki halde bir dil dilencisiyiz. Arapların, Acemlerin ve hele şimdi de Frenklerin kapılarını çalarak sözce, kuralca marifet sadakası dileniyoruz. İşte bu dilencilik rezaletinden kurtulmak için, kendi dilimizin düzeltilmesini yine kendi dilimiz içinde aramayı istiyoruz" (Akt. Arısoy, 1962: 3435) diyerek yeni kavram üretiminde izlenmesi gereken yola dikkat çeker. Banguoğlu (1967: 79) "Atatürk yol göstericiydi” alt başlı̆̆ında şöyle der; Atatürk bir dilci değildi. Atatürk büyük bir kahramandı, büyük bir devlet adamıydı. O yol gösterdi, yol açtı. O yolda çalışmalar yapmak, terimler yaratmak uzmanlara ait birşeydi. (...) Ama açtığı yolda muvaffak olmuştur. Bugün Türkçede Türkçe terim yapılmaktadır. (...) Bunu Atatürk’ün büyük cesaretine ve teşvikine borçluyuz. Lewis (2004: 99) çağdaş Türkçenin sözcük dağarcığına katkı yapan ilk üç kişinin Atatürk, Falih Rıfkı Atay ve Nurullah Ataç olduğunu belirtir.

Meşrutiyet yıllarından başlayarak yazı dilimiz önemli değişikliklere uğramıştır. Banguoğlu (1967: 78) bu alandaki yeniliklerle ilgili görüşlerini aktarmadan önce Osmanlıca denilen yazı dilini, Arapça ve Farsçadan derlenmiş söz varlığı olan yapma bir dil olarak betimler. Ve devam eder:

Eskiden konuşma dili ile yazmadık. Konuşma dili ile yazmak ayıptı Osmanlıcada. Bir ambar memuru defterine un yerine dakik yazard, buğday gelirse hinta, arpa gelirse şair, odun yerine hatap yazardı. Meşrutiyet yıllarından başlıyarak konuşma dili çok kısa bir zamanda milli bir yazı dili haline getirildi. (...) Cumhuriyetten sonra ikinci bir hamle gelmiştir. Gazeteler, romanlar, şiirler sade Türkçe yazılır olmuştu. Fakat Türk yazı dili henüz bir ilim dili haline, öğretim dili haline gelmemişti. Çünkü terimler Arapçaydı. Yüksek öğretimde olsun, orta öğretimde olsun, ilk öğretimde olsun bütün terimler Arapça ve Farsçaydı. Bu terimler devam ettiriliyordu. (...) Müstakil bir millet olmak için dilde, kültürde, iktisatta da müstakil olmak gerekir. Atatürk müstakil bir Türk dili istiyordu. (...) Türkçe terim yaptırmaya başladı. Türkçe de Arapça kadar malzemesi bol, kökleri ve üretme vasıtaları bol bir dildi. (...) Atatürk ilk Türkçe terimleri yaptırdı ve okullara gönderdi.

\section{Terim üretme / sözcük türetme}

Banguoğlu, terim yapmayı dilin kendi imkânlarıyla birtakım kelimeler yaratmak olarak açıklar. Köklere birtakım ekler getirilerek kelime oluşturulduğunu bildirir ve şöyle devam eder; Talim yerine öğretim kelimesini getirmek gibi. Öğretmek yerine -im ekini ekleyerek bir kelime yapmak. Buna üretmek deriz kelime üretmek. Yabancı kelimeler yerine Türkçe kelimeler üretmeye giriştik. Ve çok güzel kelimeler akın akın dilimize girdi. Bunları yalnız dil kurumu yapar zannedersiniz. Değil bütün milletçe yaptık bunları (1967: 79-80). Yazıcı (2007: 108) terim üretme ile ilgili kararların bir kurul tarafından alınmasını "terimlere yapay karşılık" bulunabileceği varsayımıyla doğru bulmaz.

Aksoy'a (1974: 75-76) göre dilimizi özleşip geliştirmek için dilde yeni sözcükler edinip, dili yabancı sözcüklerden arındırmak gerekir. Dile yeni sözcükler eklemenin yollarını dört başlıkta inceler:

1. Halk ağzından sözcük alma: abartmak, doruk, çaput, güleç, sergen, onarmak...

2. Eski metinlerden sözcük alma: arı, bağlam, konuk, sonuç, tanık, yanıt, yöre...

3. Yeni sözcük türetme: anı, demeç, basın, kazı, sözlük, uydu, yakıt, yayın, uçak...

4. Var olan sözcükleri birleştirme: akaryakıt, altyapı, süreç, gökdelen, yüzyıl...

Darbelnet (1972: 87) göre, bir türetme iki gereksinime cevap vermelidir: Bir yandan girdiği dil sistemiyle uyumlu olmalı, diğer yandan kullanıcılar tarafından benimsenmeli. Dizdaroğlu (1962: 7) Türkçe'de sözcük yapmanın "türetme" ve "birleştirme" olarak iki yolu olduğunu ifade eder. Ayrıca Türkçe sözleri toplama işi olan "derleme" ve eski eserlerin incelenerek Türkçe sözcüklerin ayıklanması işi olan "tarama" dile yeni sözcükler kazandırma yollarından olduğunu belirtir. Fransızca "analogie” sözcüğüne karşıllk olarak benimsenen "örnekseme" terim türetmede başvurulan yollardan biridir. Zülfikar (1991: 
159) terim türetmede örneksemenin rolüne değinir. Bu terim için “örnekleme”, "andırış”, ve "denkleşme” önerilerinin de yapıldığını söyler. Örneksemeyi sözcüğün ses ve yapı özelliklerini örnek alarak başka sözcüklerin türetilmesi olarak tanımlar. "Kuz" sözcüğünün "güney” sözcüğüne benzetilerek "kuzey" biçimiyle benimsenmesini bir örnekseme örneği olarak sunar. Banguoğlu (1967: 80), sözcük türetmede "kök" ve "ek"in anlambilimsel öğe olarak, birlikte birer anlam ortaya çıkardığı vurgular. Yeni sözcüğün anlamını bu ikisi birlikte, bir bütünlük içinde oluşturduğunu belirtir. Türetilen kelimelerin ve bunlara getirilen eklerin anlam bütünlüğünü bozmaması gerektiğine değinir. Türkçe söz dizimine göre fiil köküyle uyumlu ekleri fiil köküne, isim köküyle uyumlu ekleri isim köküne ekleyerek yeni kelime oluşturmak gerekliliğine vurgu yapar. Tersi durumda anlamsız türetmelerin ortaya çıkacağı uyarısında bulunur. Yazıcı (2007: 108), çeviri bağlamında terimleri üretimini altı başlıkta inceler:

- $\quad$ Ödünç terim: Yabancı kökenli terim; mikser.

- $\quad$ Kisaltma: Kurum, örgüt vb. baş harfleriyle oluşturulan terim; NATO.

- $\quad$ Özel ada dayalı terim: Bir aleti bulan, keşfeden vb. ile özdeşleştirilen terim; Oppenheim Disease.

- $\quad$ Karma terim: Farklı dillere ait sözcüklerin birleşiminden oluşan terim; micro havalandırma

- $\quad$ Kültür bağımlı terim: Bir nesne ve ya olgunun kültürel adı; kazıklı humma hastalığı.

- $\quad$ Yeni terim: yeni bir ürün, olgu için türetilen terim; bilgisayar.

Canım-Alkan (2016: 78) bilimsel dilinin gelişmesi ve dilde tutarlılık için yapılması gerekenleri şu şekilde sıralamıştır:

- $\quad$ Ana dilde de üretim yapma,

- Terim/yöntem/kavram/model/ölçek adlarını Türkçeleri ile birlikte öğrenme ve öğretme,

- Y Yaynlarda terim/yöntem/kavram/model/ölçek adı üzerine tartışma yapma,

- Bilimsel kitaplara/kitap bölümlerine terimce ekleme,

- $\quad$ Sözlük kullanma, yazım kılavuzu kullanma

\section{Sözcük türetme yolları}

Dizdaroğlu (1962: 7-24), Türkçede sözcük türetmeye yönelik ayrıntılı bir çalışma yapmıştır. Aşağıda genel başlıklar halinde bu eserden hareketle Türkçede türetme yöntemlerine ilişkin özet bilgiler verilmiştir:

A. Yapım ekleriyle türetme

1. İsim, sıfat, yansımadan isim ve sıfat türeten ekler

- $\quad$-lik: İsimden isim türetir; odun-luk. İsimden sıfat türetir; kış-lık. Sıfattan isim türetir; iyi-lik

- $\quad$-daş: İsimden isim türetir; arka-daş.

- $\quad$-ce: Ulus adlarından o ulusun dilini türetir; Türk-çe, İsimle sıfattan isim türetir; bulmaca, kara-ca. İsimden sifat türetir; kesme-ce. İsimle sıfattan zarf türetir; insan-ca, delice. Zamirle çoğul isimden "-e göre" anlamı veren sözcükler türetir; ben-ce, insanlar-ca. Çoğul takısı almış sayı sıfatından, çokluk anlamı veren sıfat türetir; yüzler-ce.

- $\quad$-cik: İsimle Sıfattan isim türetir; gelin-cik, kızıl-cık. İsimlerden, küçültme anlamı taşıyan sifatlar türetir; ev-cik

- $\quad$-ci: İsimden isim ve sifat türetir; demir-ci, inat-çı. 
- $\quad$-cil: İsimden isim türetir; et-çil. İsimden ssfat türetir; ölüm-cül. Sifattan sifat türetir; kır-çıl.

- $\quad$-li: İsimden isim türetir; köy-lü. İsimden sıfat türetir; üzüntü-lü Sayı adından sıfat türetir; iki-li. Sıfattan sıfat türetir; mavi-li.

- $\quad$-siz: İsimden sifat türetir; tuz-suz.

- $\quad$-men: İsimden isim türetir; göç-men. Sıfattan isim türetir; kara-man. Sıfattan sıfat türetir; şiş-man.

- $\quad$-(in)de: İsimden sıfat türetir; söz-de, yer-inde

- $\quad$-den: İsimden sifat türetir; can-dan

- $\quad$-ki: Yalın haldeki ya da -de halindeki isimden sıfat türetir; evde-ki

- $\quad$-ti: Bir yansima kendine isim türetir; gıcır-tı

2. Fiillerden isim ve sıfat türeten ekler

- $\quad$-me: Fiilden isim türetir; böl-me. Fiilden sıfat türetir; as-ma(köprü).

- $\quad$-mek: Fiilden o fiilin adı olan isim türetir; dinle-mek.

- $\quad$-iş: Fiilden isim türetir; otur-uş.

- $\quad$-(i)nti: Fiilden isim türetir; çök-üntü.

- $\quad$-ti: sonu r ile biten fiil köküne eklenip isim türetir; belir-ti.

- $\quad$-gi: Fiilden isim türetir; sil-gi.

- $\quad$-(i)m: Fiilden isim türetir; öl-üm. Sıfat görevinde kullanılan isim türetir; iç-im

- $\quad$-(e)k: Fiilden isim türetir; dur-ak. Fiilden sifat türetir; kork-ak.

- $\quad$-i: Fiilden isim türetir; yap-1. Fiilden sıfat türetir; sık-1.

- $\quad$-(in)ç: Fiilden isim türetir; bas-ınç. Fiilden sıfat türetir; gül-ünç.

- $\quad$-geç: Fiilden isim türetir; süz-geç. Fiilden sıfat türetir; utan-gaç.

- $\quad$-giç: Fiilden isim türetir; dal-giç. Fiilden sifat türetir; bil-giç.

- $\quad$-(i)n: Fiilden isim türetir; bas-ın.

- $\quad$-(i)t: Fiilden isim türetir; yaş-1t.

- $\quad$-men: Fiilden isim türetir; öğret-men.

- $\quad$-(i)k: Fiilden sifat türetir; kes-ik.

- $\quad$-gin: Fiilden isim türetir; bas-kın. Fiilden sıfat türetir; sol-gun.

- $\quad$-gen: Fiilden isim türetir; ısır-gan. Fiilden sıfat türetir; çalış-kan.

- $\quad$-ici: Fiilden sıfat türetir; yırt-ıcı. Fiilden isim türetir; koş-ucu.

- $\quad$-en: Fiilden sıfat türetir; bil-en.

- $\quad$-miş: Fiilden sifat türetir; piş-miş.

- $\quad$-(e, i)r: Fiilden isim türetir; gel-ir (kazanç anlamında). Fiilden sıfat türetir; yan-ar (dağ).

- $\quad$-mez: Fiilden sıfat türetir; anlaşl-maz.

- $\quad$-ecek: Fiilden sıfat türetir; iç-ecek (içilecek şey anlamında).

- $\quad$-dik: Fiilden isim türetir; arama-dik (yer).

- $\quad$-(i)li: Fiilden sıfat türetir; kapa-lı.

3. İsim, Sifat, Yansimadan fiil türeten ekler

- $\quad$-le: İsimden fiil türetir; kilit-le-mek. Sıfattan fiil türetir; kara-la-mak. Yansımadan fiil türetir; çın-la-mak.

- $\quad$-(e)l: Sifattan fil türetir; az-al-mak. 
- $\quad$-er: Sifattan fiil türetir; mor-ar-mak.

- $\quad$-de: 1 ve r ile biten yansımalardan fiil türetir; fisıl-da-mak

- $\quad$-kir: Yansımadan fiil türetir; tü-kür-mek.

- $\quad$-ir: Yansımadan fiil türetir; üf-ür-mek.

4. Fiillerden Fiil Türeten ekler

- $\quad$-e: tık-a-mak

- $\quad$-ele: kov-ala-mak.

- $\quad-(\mathrm{e}, \mathrm{i}) \mathrm{kle}$ s sür-ükle -mek,

- $\quad$-(i)ştir: ara-ştır-mak

Fiilin oluş biçimini değiştiren ancak anlamında değişiklik yapmayan, (edilgenlik, dönüşlülük, işteşlik, oldurganlık ile ettirgenlik) ekler yukarıya eklenmemiştir.

B. Birleştirme yoluyla türetme

1. Bileşik isimlerle yapılanlar

- İki yalın isimden; Demirkazık (kutup yıldızı).

- $\quad$ Belirtisiz isim tamlaması biçiminde; ayakkabı.

- $\quad$ Sifat tamlaması biçiminde; akciğer

- $\quad$ Yalın ya da hal takısı almış bir isimle bir çekimli fiilden; kuşkonmaz

- Yalın ya da hal takısı almış bir isimle bir fiil türevinden; dalakıran.

- $\quad$ İki çekimli fiilden; dedikodu.

2. Bileşik sıfatlarla yapılanlar

- $\quad$ İki yalın isimden: tepegöz.

- $\quad$ Sıfat tamlaması biçiminde: açıkgöz.

- $\quad$ İki çekimli fiilden; sinekkaydı, çıtkırıldım.

- $\quad$ Pekiştirme sıfatı biçiminde: vurdumduymaz.

- $\quad$ İki ya da daha çok sözcükten yapılmış belgisiz sıfat biçiminde; birçok.

Sözcük türetme yollarıyla ilgili yukarıdaki verilen özet bilgi, bir çevirmenin çeviri sırasında kavram üretiminde yapmak durumunda kalacakları türetmelerde işlerinin zorluğuna dikkati çekmek üzere verilmiştir. Bir çeviride bu tür bir durumla her gün karşılaşılmayacağı varsayılabilir. Ancak bilim ve teknolojinin hızla geliştiği çağımızda her gün yeni bir kavramın ve terimin ortaya atıldığı bu zor duruma karşı çevirmenin kendi dilinin yapısına uygun karşılıkları bulma yollarını bilmesi, yeni gelişmelerin hızına ayak uydurması gerekir. Bu durumun bir çevirmenin sırtına çok ağır yükler yüklediğini belirtmek gerekir. Gerçi bu dil bilinci herkesin taşıması gereken bir yük olarak görülmeli ve bu yönde insanların bilinçlendirilmesi gerekir. Çevirmen, çeviri sürecinde yeni kavram üretmek durumunda kaldığında genellikle izlenen yolu başlıklar halinde şöyle aktarılabilir:

- $\quad$ Yabancı terimi doğrudan aktarma: Yabancı terimi olduğu gibi aktarma.

- Türkçe sesletime uyarlama: Yabancı terimi erek dil sesletimine uyarlayarak çevirme.

- $\quad$ Yeni terim türetme: Yeni bir kavrama karşılık yeni bir terim üretme.

- $\quad$ Açımlama: Bir kavramı birden çok kavram ile açılayarak aktarma.

- $\quad$ Kültürel dengini bulma: gündelik türetilmiş karşılığını bulma. 


\section{- $\quad$ Perspektif kaydırma: Var olan bir terimin kullanım alanının değiştirilmesi (Yazıcı:109-} 110).

Banguoğlu (1967: 80-81), yabancı sözcüklere Türkçe kuralına göre türetmeler yapmak için halkın dilini adres gösterir. Buradan alınan sözcüklerle kuralına uygun yapılan türetmelerin dil zevkimize uygun olacağı, kulağımızı okşayacă̆ı değerlendirmesini yapar. Örneğin; investissement yerine yatırım, developpement yerine kalkınma, müdafaa yerine duruşma, celse yerine oturum türetmelerini yaşayan Türkçe ve doğru Türkçe türetmeler olarak niteler. İlginç sözcügünü kural dışı türetme olduğu gerekçesiyle dil yapımıza uymadığını belirtir. İnç eki fiil köküne gelir. İlgi ise isim köküdür. İsim köküne -inç eki eklenemez. O halde bu kural dışı bir türetmedir. Aynı şekilde Toplum sözcügünü -im ekinin fiil köküne geldiğini, toplu isim kökü olduğunu doğru türetmenin topluluk olduğunu açılar. Bu sözcüklerin kurallı türetme olmadığını, kulağımızı tırmaladığını belirtir. Bu tür üretmeleri uydurma olarak niteler. Lewis (2004:132), -sel/sal ekinin kullanımının Avrupa dillerinden çevirilerde çevirmene kavram üretmede kolaylık sağlayabileceğini belirtir. Ancak bu eklerin Türkçenin doğasına aykırı olduğunu belirtir. Aksoy (1980: 155), yabancı sözcüklerin, kalıplaşmış sözlerin ve tümcelerin görünüşteki biçimlerini özleştirmenin yeterli olmadığını savunur. Çeviride bunların öz kavramını üretecek Türkçe sözcükler, kalıplar, biçimler, yapılar aranıp bulunması gerekliliğini vurgular. Yoksa dilimizin yadırgadığı çeviri kokan bir sözde Türkçe ortaya çıkacağını belirtir. Bu sözde Türkçelere şunları örnek gösterir: "Bu sabah bir banyo aldım.” , “çay alır mısınız?”, “üç gün var ki sizi bekliyorum.” Ancak "Çay alır mısınız?” soru tümcesi her durumda yanlıştır diye algılanmamalıdır. Tümcenin bağlamını gözden geçirmeden bu yargıya katılmak doğru değildir. Bu paket çay alım-satım bağlamında bir satış önerisi ise yukarıdaki düşünce yanlıştır.

\section{7'de Tercüme bürosunun işlevin yitirmesine neden olan sözcüklerle ilgili}

Cumhuriyet tarihimizde 1940 yılında önemli bir çeviri atılımı gerçekleştirilmiştir. Tercüme bürosu kuruluştur. Bu büroyla ilgili Encümen raporunun girişi şu ifadelerle başlar; "Memleketimizin irfan hayatı için tercümenin bugün büyük bir ehemmiyeti olduğu herkesçe malumdur. Tercüme hem memlekette medeniyet âleminin fikirlerini ve hassasiyetini getirmek, hem de dilimizi zenginleştirmek hususunda hizmet edecektir"(Akt. Tuncel, 2004 :34). Bu büronun en temel amaçlarından birinin çeviri yoluyla yeni kavramların dilimize kazandırılması olduğu açıtır. Büronun çalışmaları Tercüme dergisiyle eşzamanlı 1967'ye kadar işlevsel olarak devam etmiş ve dergisini düzenli olarak çıkarmıştır. 23 Ocak 1967 tarihinde Tercüme Bürosu üyelerinin istifa etmiştir. Ertesi gün 24 Ocak’ta çıan bir gazete haberinin başlı̆̆ şöyledir. "Türkçeyi tahrip etmek isteyenler ayrıldı" (Türk Dili İçin V, 1967: 13). Aynı gazetenin dört gün sonra 28 Ocak 1967'de çıkan bir başka haberine "Dil ve milli kültürümüz büyük yükten kurtuldu” başlığı atılmıştır (Türk Dili İçin V, 1967:16). Haberin devamında din, milliyet ve siyaset üçlüsü bağlamındaki yorumların arasında tercüme bürosundaki heyetin "uydurma dili israrla kullanacakları” yönündeki bildirilerini şiddetle eleştirmiştir. Tercüme dergisinin son sayısındaki dil "uydurma ve gülünç" olarak nitelendirilmiştir. Burada bahsi geçen derginin son sayısı 1966 yılının Temmuz-Eylül döneminde yayınlanan 87. Sayısıdır. "Uydurma dil" ve çeviri bağlamında derginin belirtilen sayılarındaki çeviriler bu gözle ayrıca incelenebilir.

Hacıeminoğlu (1967: 26) Türk aydınının "Osmanlıca" denilen yapay dili zaten daha önce kullanmayı bıraktığını Ömer Seyfettin, Mehmet Emin Yurdakul, Cahit Sıtkı Tarancı gibi büyük "kalem sahipleri”nin güzel Türkçeyi, anlaşılır Türkçeyi kullandıklarını belirtir. Yazıyı kaleme aldığı dönemde ise "eski üstadlar” Falih Rıfkı Atay ve Yakup Kadri Karaosmanoğlu'nun bu geleneği devam ettirenlerden olduğunun altını çiziyor. Burada tercüme bürosunca yapılan çevirilerin dili ile Türk yazın geleneğinin önemli isimlerinin kullandı̆̆ı dil karşılaştırılmaktadır. Tercüme yapacaklara kimlerin kullandığı dil ile 
tercüme yapmaları gerektiğine ilişkin bir yönlendirme açıkça görülmektedir. Çevirmenler ihtiyaçlara göre dilin gelişimine katkıda bulunmayı görev bilmesi gerekenlerin başındadır. En azından böyle olması beklenir. Bu nedenledir ki çevirmen, çeviri işlemi sürecinde ana dil duyarlılığını birinci derecede önceler.

Ahmet Kabaklı (1967: 22) Tercüme dergisinde kullanılan arı dile karşı eleştirilerini dergiden bir alıntıyla ilişkilendirir:

Ussal sınırlarını matematiksel bir kesinliğe dek vardıran çağdaş bilimin acıklı durumunu düşünüyoruz; fizikte, biri genel görelik ilkesini, öbürü fiziksel ölçülerin bile sayı bakımından doğruluğunu her an için sınırlayacak bir kesinlik ve belersizlik ilkesini ileri süren bir öğretinin var olduğunu görüyoruz; içinde yaşadığımız yüzyılda, bilimde en büyük yenilikler yapan, çağdaş evrebilimi başlattıran ve en geniş bireşimleri denklem olarak kurup açıklayan bir kişinin, sıkışınca usun yardımına sezgiyi çağırdığını, "bilimsel filizlenme için en verimli toprak imgeler alanıdır" (Perse, 1966: 21)

$\mathrm{Bu}$ dizeler sonrasında tercüme heyeti üyelerinin siyasi bir bakışla hareket ettiklerini vurgulayıp kendilerine daha önceden "onursuz, biçimsiz, uydurma kuşdiliyle tercüme" yapmaları emredildiğini belirtip, bulundukları dönemde kendilerine "Halkın Türkçesiyle yazın" denilince kızmalarının nedenini sorguluyor. Acaba tercüme heyeti gerçekten kuş diliyle mi yazıyor? Burada çevirmen, tercihini yeni üretilen kavramlarla kendine özgü anlatım üstünlüğü yaratma yönünde kullanmaktadır. Yukarıdaki eleştirilerin yapıldığı dönemle çevirinin anlaşılabilirliği ile günümüz karşılaştırılırsa olumlu bir ayrım ortaya çıkar. Hacıeminoğlu (1967: 26) yaklaşık 50 yll önce istifa etmiş mütercimlerin kullandığı sözcükleri "kuş dili" ve "uydurma kelimeler" olarak görür. Bu durumu şiddetle eleştirir. Kuş dili ve uydurma dilin Türkçenin yıkılmasına, bozulmasına ve soysuzlaşmasına neden olduğunu öne sürer. İşte onlardan bazılarını seçip eleştirdiği sözcükler: Giz, gizemli, özgün, yaşam, karmaşa, özveri, görsel, görütsel, görüngü, işlevsel, ulam, usal, betimlemek, anımsamak, yadsımak, kitapcıl, ikircil, yazınsal, yerindelik, yeğlemek, bulunç, çaşıt, belit, tümel, tikel, karşın, karşıcıl. Çeviri yoluyla üretilmiş kavramların, toplum tarafından benimsenmesi için, yeni anlam sarmalında kuşatılmış kavramın o toplumun özbilincine uygun çevrede kullanım alanı bulması gerekir. Kavram, bu alana ne kadar çabuk erişirse kavramın içselleştirilmesi o derece hızlı gerçekleşir. Yukarıdaki sözcüklerin yeni kullanılmaya başladığı çevrede okuyucular tarafından alımlanması her zaman kolay olmaz. Yıldız (2017: 129), ödünçleme yoluyla tıp terimleri alınmasının tıp öğrencilerinin bunları öğrenmesini zorlaştırdığı sonucuna götüren ifadeleri vardır. Terimlerin Türkçe karşllıklarıyla öğrenmenin daha kolay olduğunu söyler. Ancak alandan bazı hocaların bu konuya farklı yaklaşımını öğrencilere söylediklerinden anlaşıldığını belirtiyor; "Siz artık doktor olacaksınız. Halkın ağzıyla konuşmayın, teknik terimle konuşun” Bu hocaların derslerinde Türkçe terimleri kullanmalarını istemenin etkili olmayacağını ifade eder. Dante’nin "İlahi Komedya" adlı eserinin "Tanrısal Komedya" (Eliot, 1966: 56) olarak çevrilmesi ve bu çevirinin bugün kullanılmaması toplumsal benimseyiş ile ilgili bir durumdur. Eleştirdiği sözcüklere değin yazarın düşüncesini birebir aktarıyoruz: "Biz bu kelimelerin hiç birini anlayamadık. Çoğunu sözlüklerde bulmak da imkânsızdır. Hepsini demiyoruz, çünkü bunların bir kısmı Dil Kurumu'nun uydurma kelimelerini ihtiva eden "Türkçe Sözlük" ünde vardır. Fakat kimse tarafından bilinmez ve kullanılmaz." (Hacıeminoğlu, 1967: 27). Coşkun ve Gümüşoğlu (2019: ); sözlüklere kelime alınmasına ilişkin şu bilgileri verir; Fransızca sözlük yayıncılığında söz sahibi Robert ile Larousse sözlükleri her yıl yayınladıkları yeni baskılarında güncel ve dilde kullanımı kabul görmüş kelimelere yer vermektedirler. Le Robert 2018 için 300; 2019 için 250 ve 2020 için 109 yeni kelimeyi sözlüğe eklemiştir. Larousse 2018 için 160; 2019 için 160 ve 2020 için 150 yeni kelimeyi sözlüğe katıp yayınlamıştır. Larousse sözlükleri her sene sık kullanılanlar arasından özellikle 150 kelimeyi seçip eklemektedir. Bu sayı üç aşağı beş yukarı azalıp artabilmektedir. Böylelikle dillerinin gelişimine de önemli katkıda bulunmaktadırlar. Verilen 
bilgilerden yola çıkarak bir dilde kullanım alanı bulan bir kavramın sözlüklerde yerini alması için kaybolmadan olgunlaşıp belli bir süre kullanım alanı bulmasına bağlıdır sonucuna varılır. Bir çevirmenin ürettiği kavramların güncel sözlüklerde çabucak yer bulmamasının nedeni bu şekilde açıklanabilir. Çeviri eleştirisi bağlamında bir yorumda Pamir tarafından yapılmıştır. Pamir (1967: 32), Melahat Özgü'nün Schiller'den çevirdiği "İnsanın Estetik Eğitimi Üzerine Bir Dizi Mektup” adlı çalışmadan seçilen "uydurma kelimeleri", "millete ibretle okusun" diye sıralar: erke, erinç, eytişim, utkulu, gereç, yaşam, betimleme, yeğlemek, dizge, çevren, simge, yığınmak, ussal, öznel, törel, göreli, anlak, örgenli, görünü, tansımak, etke, tanıtlamak, yapıt, yabanıl, görü, ayrıksız, saptamak, özelge, kurgu, kargış, koşullamak, savut, anık, tinsel düzün, yönergilendirmek, bulunç, tansık, ulam, kalıt, yabansıl, dizem (sistem), dizge (o da sistem), doğa (dünya), doğa (tabiat, yaratılış), erkeçe (enerjik), erkesel (o da enerjik), giz (sır), gizlem (gene sır), gizem (o da sır). Gerçektende yukarıda verilen sözcükleri okurken çok önemli dersler çıkarıyoruz. Yazıcı (2007: 108), bir dilde terimlerin yerleşmesine ilişkin "Kavram toplumda işlevsellik kazandıkça ana dilde karşllı̆ı̆ı bulur" der. Nezihi (1967: 35), Pamir'in gazetede çıkan bir yazısına gönderme yaparak mütercimlerin çevirmenlerin tercüme ettikleri kitaplarda kullanılan sözcüklere örnekler vermektedir: bu kelimelerle yazılan metinlerin tekrar Türkçeye çevrilmesi gerektiğine yönelik sözler kullanmaktadır. Bu kelimeleri inceleyelim: giz, gizemli, özgün, yaşam, karmaşa, özveri, görsel, görütsel, görüngü, işlevsel, ulam, betimlemek, anımsamak, yadsımak, kitapçıl, ikircil, yazınsal, yerindelik, yeğlemek, bulunç, çaşıt, belit, tümel, tikel, karşın, karşıcıl. Erer (1967: 39-40) Türk Dil Kurumu tarafından 1966 yllında 250 ve 251 sayıyla yayınlanan iki hukuk dili terimlerini içeren sözlügü eleştirmektedir. Arka arkaya yayınlanan bu sözlüklerde Osmanlıca (Arapça, Farsça kökenli) bazı sözcükler için verilmiş karşılıkların biri diğerinden farklı olduğuna yönelik tespitlerini sıralar. Bu çeşit bir tutumu tutarsızlık olarak yorumlar. Benzer yaklaşımları dili bozmaya yönelik arayışlar olarak niteler. İşte eleştiriye konu olan içerik:

Tablo 1. Farklı türetilen kelimeler

\begin{tabular}{|l|l|l|}
\hline Osmanlıca Sözcük & 1. Kitaptaki Karşıll̆̆ı & 2. Kitaptaki Karşılı̆̆ı \\
\hline Adliye & Adalet & Tüze \\
\hline Vekâleti & Bakanlı̆̆ & Bakanlı̆̆ı \\
\hline Aidat & Kesenek & Ödenti \\
\hline Amel & Edim & İş \\
\hline Âmir & Üst & Buyurucu \\
\hline Beyan & Bildiri & Açıklama \\
\hline Beyyine külfeti & İsat ödevi & Tanıt yükü \\
\hline Fasıl & Bölüm & Kesim \\
\hline Fert & Kişi & Birey \\
\hline Gaye & Amaç & Erek \\
\hline Hissedar & Ortak & Paydaş \\
\hline İcap & Gerek & İster \\
\hline İddia etmek & Ortaya atmak & savlamak \\
\hline İfade & Deyim & Anlatım \\
\hline İhtimam & Bakım & Özen \\
\hline İkrâr & Tanıma & Söyletmek \\
\hline İntifa & Aşlanma & Kullanma \\
\hline
\end{tabular}




\begin{tabular}{|l|l|l|}
\hline İşgal & Tutmak & Kapım \\
\hline Kabul & Toplama & Benimsemek \\
\hline Kararlı & Kökleşmiş & Kıyılgı \\
\hline Kayıt & Yazılma & Yazgı \\
\hline
\end{tabular}

Fenik (1967: 44-45) tercüme bürosunda uydurma sözcüklerle yapılan anlaşılmaz tümcelere örnekler verir ve bu duruma şiddetle karşı çıkar. Yazısında verdiği örnekleri şunlardır:

\section{Onun istemi bizim erinçliğimizdir!}

Duygan, seyirci de, biçimi anımsadıklarının bir betimi olarak değil, görmeyi koşullamalıdır.

Gerçekten de verilen tümcelerde anlam derinliği bulmakta zorlanılmaktadır. Bu durum yeni türetilen kelimelerin sık kullanımıyla ilgili bir çözümsüzlüğü beraberinde getirir. Bununla birlikte yukardaki tümcelerin bağlam içinde kullanımını görüp, ardından çeviriyi yorumlamak daha doğrudur. Ayrıca Roland Desmarests çeviri ile ilgili şu sözünü bu bağlamda göz önünde bulundurmakta yarar vardır; "Bence çeviriyi en az hatırlatan, en iyi çeviridir. (Epistolae philologicae [1651], akt. Zuber, 1968: 104) Fenik (1967: 44-45) eleştirisinde şu kelimelerin sözlükte bile anlamı bulunmadığını ifade eder: özgün süreç, gizem, belit, emsel, eytiş.

Burada yeni türetilen kavramlarla ilgili sözcüklerin sözlükte bulunmayışı ile ilgili bir serzeniş vardır. Dile yeni giren bir sözcüğün sözlüklerde yer almasına kısaca değinilmişti. Acaba eleştirilen sözcüklerin bugünkü sözlüklerdeki yeri nedir?

Özgün: 1. sıfat Yalnız kendine özgü bir nitelik taşıyan, orijinal, ibdai: "Eskinin doğa ile uyuşan, özgün yapılarını yıkıp yerine yabancı, öykünme, yaratıcılıktan yoksun yapılar dikerek çirkinleştirdik." Necati Cumalı. 2. sıfat Bir buluş sonucu olan, nitelikleri bakımından benzerlerinden ayrı ve üstün olan: Özgün biçim. 3. sıfat Çeviri olmayan, asıl olan (metin), orijinal.

Süreç: Aralarında birlik olan veya belli bir düzen veya zaman içinde tekrarlanan, ilerleyen, gelişen olay ve hareketler dizisi, vetire, proses: "Kitaba aldı̆̆ım bu yazılar, gerçekte siyasal kavgamın gelişme sürecinde önemli bir tavır takınmayı vurgulamaktadır." - Attila İlhan

Gizem: Sir.

Belit: Kendiliğinden apaçık ve bundan dolayı öteki önermelerin ön dayanağı saylan temel önerme, mütearife, aksiyom: “Tüm, parçaların her birinden büyüktür" sözü bir belittir.

Emsel: Bu söz bulunamadı.

Eytiş(im): Diyalektik.

Görüldüğü gibi sözcüklerin zamanla dile yerleşmesi yaşaması ve yok olması dil evreninin doğal bir olgusudur.

Kabaklı (1967:48-50) tercüme bürosu üyelerinin yaptığı çevirilerin içinden bilinmeyen ve anlaşlamayan sözcükleri aktarır ve bu durumu "müdafaası mümkün olmayan bir uydurmacllı" olarak görür. Bunlara örnek olarak şu sözcükleri verir: özgün süreç, gizem, belit, kutsanmışlık, betimlemek, görüngüsel, yazımsal, yanıtlamak, eytişimsel, simgeci, töz, savut, görsel yazın, kurgu, görüt, esinlemek, yöresel, tümce, anımsamak.

Atatürk Güneş-Dil Teorisi'den etkilendiği bir dönemde, 1936 yılı Mart sonlarında bir akşam sofrasında, var olan Türk edebî diline yerleşen tüm kelimelerin Türkçe sayılmasına ilişkin; "Kitap, kâtip, mektup benimdir, ketebe yektübü arabındır. Herkesin söylediği yazdığı kitap, kâtip mektup, Türkçedir.” 
demiştir (Dünya, 27 Haziran 1966, Akt. Bayrakdaroğlu, 1967: 51-54). Falih Rıfkı Atay, Atatürk’ün düşüncesinde özleşme denemesinin durmasını şöyle aktarır (Dünya 3 Ocak 1954, akt. Bayrakdaroğlu):

Türkçeyi ne kadar özleştirebiliriz? Her yabancı kelimenin öztürkçe karşılığı bulunacağını iddia eden dilciler ne dereceye kadar haklıdırlar. Atatürk bunu denemeye karar verdi. Şimdi hiçbirimizin manasını bilmediğimiz "baysal utku” onun resmî bir nutkunda kullanılmıştır. Bir gün beni yanına doğru çekip:

“-Çocuk çıkmaza girmişizdir. Dili bu çıkmazda bırakamayız. Tabiî yola döneceğiz”, demişti. Özleşme denemesi de orada durdu idi.

Ozansoy (1967: 57-58) "dilcilerin" işi dil ya da kelime yapmak değil; dili inceleyip toplum tarafından ne zaman ve nasıl olduğu bilinmeyen ortak yaratma gücüyle doğup gelişen, yaşayan sözcükleri ve kuralları "Türk dilinin nüfus kütüğüne geçirmek" olduğunu savunur. Otuz yıldır devam eden "dil savaşında" dilin kaybettiğini düşünür.

Manevî varlıklar, milli değerler vardır ki, pek dokunulmaya gelmez. Dil bunlardan biridir. Ona dışarıdan gelecek en hafif temas, kelebek kanadına dokunan hoyrat el gibi, varlığını zedeler, ahengini, büyüsünü bozar. (...) Biz Türk Dilinin varlığına inanıyor, onu seviyor; tarihî veraseti, soylu gelenekleri ve yaratıcı imkânları içinde, rahatça gelişerek, üreyerek yaşamasını istiyoruz. Karşımızdakiler Türk dilinin var olduğuna inanmıyorlar. (...) ... onlara hatırlatalım ki, bir dil toplumun ortak eseridir Yaratıcısı gibi mantığı da tartışılamaz. O bir gerçektir. Görülür ve olduğu şekilde kabul edilir.

Maliye Bakanı Cihat Bilgehan (1967) bütçe müzakerelerinde dil konusuna ilişkin İsmet İnönü’ye yanıt verdiği konuşmasında, tercüme bürosundan ayrılanların yaptıkları çevirilerde kullandıkları bazı sözcükleri şu şekilde sıralar: erkece, kargış, savutlar, tinsel, eytişim, yönsem, dizge, törel, tepizlemek, olgular, eni konu düşlemediğini, yanılsama, yazınsal, yatsımak, gizemci, bellek, anımsatmak, algılamak, abartılmak, öykünmek, açınım, koşuk, görgütçü, eleştirisel, olasallık. Yukarıda verilen alıntının aynısını kullanan Tevetoğlu (1967: 73) 16 Şubat 1967'de "Tabî̀ Senatörlere Cevap" verdiği konuşmasında Tercüme Dergisinin 73 ve 74. Sayısındaki “uydurma dilin, acıklı dilin, acıklı örneklerini, facialarını" Nobel ödüllü Saint John Perse’nin bir eserinden yapılmış çeviriyle örneklendirir;

\begin{abstract}
"Ussal sınırlarını matematiksel bir kesinliğe dek vardıran çă̆daş bilimin acıklı durumunu düşünüyoruz. Fizikte biri genel görelik ilkesini, öbürü fiziksel ölçülerin bile sayı bakımından doğruluğunu her an için sınırlayacak bir kesinlik ve belersizlik ilkesini ileri süren bir öğretinin var olduğunu görüyoruz. İçinde yaşadığımız yüzyılda bilimde en büyük yenilikler yapan çağdaş evre bilimi başlattıran ve en geniş bireşimleri denklem olarak kurup açıklayan bir kişinin sıkışınca usun yardımına sezgiyi çă̆ırdığını bilimsel filizlenme için en verimli toprak imgeler alanıdır, dediğini duyuyoruz da şiir yolunu mantık yolu kadar yasalı sayma hakkımız olmuyor mu artık."
\end{abstract}

Senatör tercüme bürosundakilerin eserin çevirisinde kullandıkları dili "kuş dili" olarak nitelendirip çeviriyi de "kuşa çevrilmiş" bir eser olarak betimler. Çeviri. Victor Hugo şu ünlü benzetmeyi yapar: Çeviri; bir sıvıyı geniş ağızlı bir sürahiden, ağzı daracık bir sürahiye aktarmaktır: Aktarırken kayıp kaçınılmazdır. Yine çeviri bağlamında başkalarının düşüncelerini aktarmanın güçlüğüyle ilgili Michel de Marolles (1653), Les satyres de Juvenal'inin önsözünde, "Başkalarının düşüncelerini yazmak kendi düşüncelerini yazmaktan daha zordur.” der. (Akt. Zuber, 1968: 137). Lilova,(1982:174) toplumların kültür tarihi incelendiğinde, özgün yazın yalıtlanırsa, öteki ulusal yazınlarla temasta bulunmaktan, karşılıklı etki ve etkileşimden çekinirse, çeviri yazınını bir yana iter ve küçümserse başarılı bir gelişme gösteremeyeceğini belirtir. Tevetoğlu da anlamadı̆̆ı sözcükleri eleştirmekten geri durmaz: ürkü, özgün, süreç, kusuntu, gizem, belit, betinlemek, görüngüsel, işlev, ulam, betik, yazınsal, Ozan Sfokles, sunak, dinginlik, obartmalı, saptadıkları. 
Zülfikar (1991: 149) terim yapmanın yollarına değindiği çalışmasında, son yıllarda batıda üretilen fen ve teknik terimlerdeki hızlı artışa eşzamanlı olarak karşılık bulmanın pek olanaklı olmadığına değinip bu terimler için önerilen bazı karşılıkların benimsenmediğini belirtir. Buna türetilen kelimelere karşı bir inançsızlık doğmasının yol açtığını belirtir. Terimlere uygun Türkçe karşılıklar bulma sorunu konusunda; genellikle "bireysel çabalara bırakıldığı" çoğunlukla da "çeviricilerin elinde kaldığı" çıkarımını yapmaktadır. Burada çevirmenlere kavram üretimi konusunda öznel bir eleştiri yapıldığı görülmektedir. Çalışma boyunca eleştirilen sözcükler aşağıda bir liste halinde verilmiştir.

Tablo 2. Eleştirilen kelime listesi

\begin{tabular}{|l|l|l|}
\hline Abartılmak & Görü & Törel \\
\hline Açınım & Görüngü & Töz \\
\hline Algılamak & Görüngüsel & Tümce \\
\hline Anık & Görünü & Tümel \\
\hline Anımsamak & Görüt & Ulam \\
\hline Anımsatmak & Görütsel & Usal \\
\hline Anlak & İkircil & Ussal \\
\hline Ayrrksız & İşlev & Utkulu \\
\hline Belit & İşlevsel & Ürkü \\
\hline Bellek & Kalıt & Yabanıl \\
\hline Betik & Kargış & Yabansıl \\
\hline Betimleme & Karmaşa & Yadsımak \\
\hline Betimlemek & Karşıcl & Yanılsama \\
\hline Bulunç & Karşın & Yanıtlamak \\
\hline Çaşıt & Kitapcıl & Yapıt \\
\hline Çevren & Koşuk & Yaşam \\
\hline Dinginlik & Koşullamak & Yadsımak \\
\hline Dizem & Kurgu & Yazımsal \\
\hline Dizge & Kusuntu & Yazın \\
\hline Doğa & Kutsanmışlı & Yazınsal \\
\hline Düşlemek & Abartmalı & Yeğlemek \\
\hline Eleştrisel & Olasallı & Yerindelik \\
\hline Emsel & Olgular & Yı̆ı̆nmak \\
\hline Enikonu & Ozan & Yönergelendirmek \\
\hline Erinç & Örgenli & Yönsem \\
\hline Erke & Öykünmek & Yöresel \\
\hline Erkece & Özelge & \\
\hline Erkeçe & Özgün & \\
\hline Erkesel & Öznel & \\
\hline Esinlemek & Özveri & \\
\hline Etke & Saptamak & \\
\hline & & \\
\hline
\end{tabular}




\begin{tabular}{|l|l|l|}
\hline Eytiş & Savut & \\
\hline Eytişim & Simge & \\
\hline Eytişimsel & Simgeci & \\
\hline Gereç & Sunak & \\
\hline Giz & Süreç & \\
\hline Gizem & Tanıtlamak & \\
\hline Gizemci & Tansık & \\
\hline Gizemli & Tansımak & \\
\hline Gizlem & Tepizlemek & \\
\hline Göreli & Tikel & \\
\hline Görgü̈çü & Tinsel & \\
\hline Görsel & Tinsel dü̈zün & \\
\hline
\end{tabular}

Yukarıdaki listedeki toplam sözcük sayısı 113’tür. Bunlardan 78’i artık yaşamın her alanında karşımıza çlkabilecek kadar benimsenmiş ve Türkçenin zenginliği olmuştur. Toplum eleştirilen sözcükleri türetildikleri zamana göre daha çok benimseyip, "kuşdili” olmaktan çıkarıp, günlük dilde kullanır olmuştur. Bu sözcüklerin yaklaşık 35 tanesinin sözlükte anlamlarının bulunmasına karşın kullanım belli alanlarla sınırlı olduğu şeklinde yordanmaktadır. Bu kelimeler listede sağa dayalı ve koyu yazılmıştır. Diğer dilde yeniden yazma süreci olan çeviri kayıp ve kazançların birlikte değerlendirilmesi gereken bir alandır. Anlam kayması ve değişiklerin oluşabildiği bir alandır. Yukarıdaki tabloda ağır eleştirilere uğramış sözcükler birarada verilmiştir. Hazırlanan tabloda bu sözcükler alfabetik sıralanmış sıralamada sağa dayalı ve koyu yazılmıştır. Bu sözcüklerin günümüzde kullanım alanı pek de sık değildir. Ancak sonraları bu sözcüklerden başka sözcükler türetilip dilimiz zenginleştirilmiştir.

\section{Sonuç}

Cumhuriyetin ilk yıllarından itibaren önemsen kavram üretimi sorunu yıllar geçtikçe kendi doğal türetme yoluna yeniden girmiştir. Türk dilindeki yenileşme, özleşme arılaşma çalışmaları ile ilgili şöyle bir çıkarım yapılabilir. Türk dilinin zenginleşmesi, arılaşması, doğal akışını devam ettirmesi için devlet eliyle yapılmış bir şok tedavidir. Bu tedavinin sonuçlarını gözlemlemek dil kullanıcılarına düşüyor. 6o'lı yıllarda birçok çevirmen tarafından hastalığa çare olarak düşünülen yukarıda sıralanan (bkz. Tablo 2) sözcükler o günlerdeki eleştirilerle birlikte değerlendirilip üzerinde uzun uzun düşünülmeli. Çevirmenler yabancı terimlere daha dile yerleşmeden karşılık önererek bu terimlerin kullanımı üzerinde durmalıdır. Bu noktada çevirmenler bir terimbilimci gibi çeviri sürecine yaklaşıp, ana dil zenginleçtirici çalışmaların bilincinde olmalıdır. Diğer taraftan çevirmen kendisine yapılan eleştirileri bir güdüleme aracı olarak görmeli, gerektiğinde Türkçenin geleceği için “kuşdili” konuşmayı sürdürmelidir. Bu süreçte ve sonrasında öztürkçe / arı dil kullanımı yanlısı ve karşıtlığı bağlamında karşılıklı eleştiriler yapılmıştır. Kültür tarihimizin bu dönemi çeviri eserlerde arı dil ve öztürkçe kullanımının en belirgin görüldüğü dönemdir. Bu dönemde yapılan çevirilerde anlam kopuklukların oluşması, kullanılan sözcüklerin anlaşlabilirliği ile ilişkilendirilebilir. Ancak bu durum sadece çeviri alanına özgü bir durum da değildir. Edebiyatta "okunması ve anlaşılması zor" ya da "dilinin ağır olması" gibi açıklamaların bu bağlamda benzerliğini ortaya koymak gerekir. Böyle bir anlaşlmazlık edebiyatta çözümleme ve açılamalarla giderilebilir. Çeviride ise toplumun üretilen kavramları benimseyip içselleştirmesiyle giderilebilir. 


\section{Kaynakça}

Aksan, D. (1982) Her Yönüyle Dil Ana Çizgileriyle Dilbilim 3. Cilt. Ankara: Türk Dil Kurumu.

Aksoy, Ö.A. (1975) Gelişen ve Özleşen Dilimiz. Ankara: Türk Dil Kurumu.

Aksoy, Ö.A. (1980) Dil Yanlışları. Ankara: Türk Dil Kurumu.

Arısoy, M. S. (1962) Arı Dile Doğru 1, TDK Tanıtma Yayınları Radyo Konuşmaları. Ankara: Ankara Üniversitesi.

Arısoy, M. S. (1962) Arı Dile Doğru 3, TDK Tanıtma Yayınları Radyo Konuşmaları. Ankara: Ankara Üniversitesi.

Banguoğlu, T. (1967) Prof. Banguoğlu’nun “Türk Dili” Savunması, Türk Dili İçin V, Türk Kültürünü Araştırma Enstitüsü, s.s. 77-88, Ankara.

Bayrakdaroğlu, E. (1967) İlmi Yenen Bir Vehim, Türk Dili İçin V, Türk Kültürünü Araştırma Enstitüsü, s.s. 51-54, Ankara.

Bilgehan, C. (1967) 1967 Bütçe Müzakereleri Sirasında Maliye Bakanı Cihat Bilgehan'ın Dil Mevzuunda İnönü’ye Cevabı, Türk Dili İçin V, Türk Kültürünü Araştırma Enstitüsü, s.s. 69-70 Ankara.

Canım-Alkan, S. (2016) Türkçe Akademik Yazımda Çeviri ve Terim Sorunları, İstanbul Üniversitesi İşletme Fakültesi Dergisi Vol/Cilt: 45, No/Sayı:1, May/Mayıs 2016, 78-79

Coşkun, O. ve Gümüşoğlu, A. (2019) Franszzca Sözlüklere Yeni Eklenen Kelimelerle Çeviri Uygulamalar, VI. Ylldız Uluslararası Sosyal Bilimler Kongresi, 12-13 Aralık 2019, Tam Metin Bildiri Kitabl, s.s. 1085-1103, İstanbul.

Darbelnet, J. (1972). Réflexions sur la néologie. Meta, Journal des traducteurs, 17 (2), 87-93.

Dobossy, L. (1982) Sanat Yapıtı ve Estetik Araştırmalar Konusu Olarak Çeviri, Çev: Sema Rıfat Güzelşen, Yazko Çeviri, S.4 Ocak - Şubat 1982, s.s.165-167, İstanbul

Dizdaroğlu, H. (1962) Türkçe’de Sözcük Yapma Yolları. Ankara: Türk Dil Kurumu.

Eliot, T.S. (1966) Dante, (Çev. Akşit Göktürk) Tercüme, Sayı 87, ss-40-76, Ankara: MEB Tercüme Kurulu, Ankara Üniversitesi.

Erer, T. (1967) Buna Ne Diyeceksiniz? Türk Dili İçin V, Türk Kültürünü Araştırma Enstitüsü, s.s. 39-42, Ankara.

Fenik, A. (1967) Tercümeye Muhtaç Tercümeler, Türk Dili İçin V, Türk Kültürünü Araştırma Enstitüsü, s.s. 44-45, Ankara.

Hacıeminoğlu, N. (1967) Mütercimlerin İstifası ve Bazı Gerçekler, Türk Dili İçin V, Türk Kültürünü Araştırma Enstitüsü, s.s. 20-21, Ankara.

Kabaklı, A. (1967) Tercüme Bürosu, Türk Dili İçin V, Türk Kültürünü Araştırma Enstitüsü, s.s. 20-21, Ankara.

Lewis, G. (2004) Trajik Başarı-Türk Dil Reformu, (Çev. Mehmet Fatih Uslu). İstanbul: Gelenek.

Lilova, A. (1982) Uluslararası Çevirmenler Federasyonu Başkanı Anna Lilova İle Konuşma, Yazko Çeviri, S.5, Mart - Nisan 1982, s.s.174-177, İstanbul.

Nezihi, M. (1967) Yine Tercüme Heyeti, Türk Dili İçin V, Türk Kültürünü Araştırma Enstitüsü, s.s. 3536, Ankara.

Ozansoy, M. F. (1967) Kutsal Savaş, Türk Dili İçin V, Türk Kültürünü Araştırma Enstitüsü, s.s. 57-58, Ankara.

Pamir, A. (1967) Tercüme Facialarnnı Kahramanları, Türk Dili İçin V, Türk Kültürünü Araştırma Enstitüsü, s.s. 30-32, Ankara.

Perse, S.-J. (1966)Tercüme, Sayı 73-74, s.s. 21, Ankara: MEB Tercüme Kurulu, Ankara Üniversitesi. 
Tevetoğlu, F. (1967) Senatör Dr. Fethi Tevetoğlu’nun Senatoda Dil ve Tercüme Bürosu Hakkndaki Konuşması (Tabiî Senatörlere Cevap 16 Şubat 1967), Türk Dili İ̧̧in V, Türk Kültürünü Araştırma Enstitüsü, s.s. 71-74, Ankara.

Tuncel, B. (2004) Hasan-Âli Yücel ve Tercüme, Çeviri Seçkisi I, Haz. Mehmet Rifat. İstanbul: Sel.

Vardar, B. (2001) Dilbilim Yazıları. İstanbul: Multilingual.

Yücel, T. (2000) Türkçenin Kurtuluş Savaşı. İstanbul: Cumhuriyet.

Yazıcı, M. (2007) Yazılı Çeviri Edinci. İstanbul: Multilingual.

Ylldı, M. (2017) Bilim Dili Bağlamında Dil Ve Kimlik. Kocaeli: Umuttepe.

Zülfikar, H. (1991) Terim Sorunları ve Terim Yapma Yolları. Ankara: Türk Dil Kurumu.

Zuber, R. (1968) Les “Belles infidèles" et la formation du goût classique, Armand Colin, Paris. 